\title{
Evolution of the sintering ability, microstructure, and cell performance of $\mathrm{Ba}_{0.8} \mathrm{Sr}_{0.2} \mathrm{Ce}_{0.8-x-y} \mathrm{Zr}_{y} \ln _{x} \mathrm{Y}_{0.2} \mathrm{O}_{3-\delta}$ $(x=0.05,0.1 y=0,0.1)$ proton-conducting electrolytes for solid oxide fuel cell
}

\author{
Kai-Ti HSU,,${ }^{* \dagger}$ Yu-Jing REN, ${ }^{*}$ Han-Wen CHEN, ${ }^{*}$ Pei-Hua TSAI, ${ }^{*}$ Jason Shian-Ching JANG, ${ }^{*, *,+\dagger}$ \\ Chi-Shiung HSI, ${ }^{* * *}$ Jing-Chie LIN, ${ }^{* * *}$ Jeng-Kuei CHANG, ${ }^{*}$ Sheng-Wei LEE ${ }^{*}$ and I-Ming HUNG**** \\ *Institute of Materials Science and Engineering, National Central University, Taoyuan 32001, Taiwan, ROC \\ ** Department of Mechanical Engineering, National Central University, Taoyuan 32001, Taiwan, ROC \\ *** Department of Materials Science and Engineering, National United University, Miaoli 36003, Taiwan, ROC \\ ${ }^{* * * *}$ Department of Chemical Engineering and Materials Science, Yuan-Ze University, Taoyuan 32003, Taiwan, ROC
}

\begin{abstract}
$\mathrm{Ba}_{0.8} \mathrm{Sr}_{0.2} \mathrm{Ce}_{0.8-x-y} \mathrm{Zr}_{y} \mathrm{In}_{x} \mathrm{Y}_{0.2} \mathrm{O}_{3-\delta}(x=0.05,0.1 y=0,0.1)$ proton-conducting oxides are prepared using a solid state reaction process. The effect of indium contents on the microstructures, chemical stability, electrical conductivity, and sintering ability of these $\mathrm{Ba}_{0.8} \mathrm{Sr}_{0.2} \mathrm{Ce}_{0.6} \mathrm{Zr}_{0.2} \mathrm{In}_{x} \mathrm{Y}_{0.2-x} \mathrm{O}_{3-\delta}$ oxides were systemically investigated by $\mathrm{X}$-ray diffraction (XRD), scanning electron microscopy (SEM), and two probe conductivity analysis. The results reveal that the $\mathrm{Ba}_{0.8} \mathrm{Sr}_{0.2} \mathrm{Ce}_{0.6} \mathrm{Zr}_{0.2} \mathrm{In}_{x} \mathrm{Y}_{0.2-x} \mathrm{O}_{3-\delta}$ oxides are cubic perovskite crystal structure without second phase. Surface morphology of $1450^{\circ} \mathrm{C}, 4 \mathrm{~h}$ sintered oxides shows a dense microstructure. The optimum conductivity of $\mathrm{Ba}_{0.8} \mathrm{Sr}_{0.2} \mathrm{Ce}_{0.75} \mathrm{In}_{0.05} \mathrm{Y}_{0.2} \mathrm{O}_{3-\delta}$ oxide is $0.011 \mathrm{~S} / \mathrm{cm}$ measured at $800^{\circ} \mathrm{C}$. Chemical stability of the oxides to resist $\mathrm{CO}_{2}$ at $600^{\circ} \mathrm{C}$ is effectively improved by doping 0.1 at \% indium or more. In addition, the laminated electrolyte and anode layers which fabricated by tape casting were co-sintered at $1450^{\circ} \mathrm{C}$ for $4 \mathrm{~h}$. The sintered half-cell coated with Pt paste as cathode was used for I-V curve performance testing. The performance of the single cell of anode supported protonsolid oxide fuel cell $\left(\mathrm{P}^{+}-\mathrm{SOFC}\right.$ ) have powder density of $139.8 \mathrm{~mW} / \mathrm{cm}$ at $800^{\circ} \mathrm{C}$. Therefore, the $\mathrm{Ba}_{0.8} \mathrm{Sr}_{0.2} \mathrm{Ce}_{0.75} \mathrm{In}_{0.05} \mathrm{Y}_{0.2} \mathrm{O}_{3-\delta}$ ceramic is suggested to be a potential electrolyte material for $\mathrm{P}^{+}$-SOFC applications.
\end{abstract}

(02015 The Ceramic Society of Japan. All rights reserved.

Key-words : Solid oxide fuel cells, Sintering, Electrical conductivity, Chemical stability, Electrolyte, Indium doping

[Received December 15, 2014; Accepted January 29, 2015]

\section{Introduction}

Solid oxide fuel cells (SOFCs) have attracted great attentions as a promising alternative energy technology with no pollutant emissions in recent years due to its high energy conversion efficiency, low environmental impact, and ability to use nonprecious-metal catalysts. ${ }^{1-3)}$ The solid electrolytes of SOFCs are composed of oxygen-ion conducting electrolyte $\left(\mathrm{O}^{2-}-\mathrm{SOFC}\right)$ and usually required to operate at the high temperature around 800 $1000^{\circ} \mathrm{C}$, because the high temperature has benefit on the electron conductivity and oxygen ions migration in the electrolyte. Operating at high temperature results in a series problem such as rapid sintering of electrode, high activation reaction between cell components and intermediate connecting materials, ${ }^{4-6)}$ which cause the degradation of fuel cells performance and reducing their lifetime. Reducing the working temperature of SOFCs to the intermediate-temperature ranges $\left(500-800^{\circ} \mathrm{C}\right)$ is considered to be more applicable. Recently, there have been devoted to develop the proton-conducting solid oxide fuel cells which can operate at relatively low temperature. This facilitates the selection of the sealing and interconnection materials, control of the interactions

Corresponding author: K.-T. Hsu; E-mail: kady0525@hotmail. com

$\dagger$ Corresponding author: J. S.-C. Jang; E-mail: jscjang@ ncu.edu.tw

tit Preface for this article: Dol http://dx.doi.org/10.2109/jcersj2.123.P4-1 between the electrode/electrolyte, and prolongs the operation lifetime. ${ }^{7-9)}$

Proton conducting electrolytes are promising candidates of membrane materials for SOFC operating at intermediate-temperature because of their higher conductivity and lower activation energy. ${ }^{10)}$ In 1980, Iwahara and coworkers ${ }^{11)}$ first revealed that $\mathrm{SrZrO}_{3}$ and $\mathrm{LaYO}_{3}$ were proton conduction in perovskites. Perovskite-type ceramics such as $\mathrm{SrCeO}_{3}, \mathrm{BaCeO}_{3}, \mathrm{SrZrO}_{3}$, and $\mathrm{BaZrO}_{3}$ doped with rare-earth oxides were found to exhibit protonic and electronic conductivity. ${ }^{12)}$ Among these perovskite conductors, the $\mathrm{BaCeO}_{3}$-based perovskite ceramics present much higher mixed proton-electron conductivity. However, they all exhibit very poor chemical stability in both $\mathrm{CO}_{2^{-}}$and $\mathrm{H}_{2} \mathrm{O}-$ containing atmospheres. ${ }^{13)}$ The $\mathrm{BaCeO}_{3}$-based perovskite ceramics form carbonates in $\mathrm{CO}_{2-}$ and $\mathrm{H}_{2} \mathrm{O}$-containing atmospheres and result in degradation of their protonic and electronic conductivity. Therefore, it's important to development a high conductivity, dense, chemical stable, and good mechanical strength electrolyte materials on $\mathrm{P}^{+}$-SOFCs.

In additions, the $\mathrm{BaCeO}_{3}$ proton conductor can be improved by partially substituting $\mathrm{Ce}$ with $\mathrm{Y}$ for $\mathrm{BaCe}_{1-x} \mathrm{Y}_{x} \mathrm{O}_{3}$, since doping with lower-valance cations create oxygen vacancies and increases the protonic conductivity. Investigations on the issue of $\mathrm{BaCe}_{1-x} \mathrm{Y}_{x} \mathrm{O}_{3}$ substituting $\mathrm{Ce}$ with $\mathrm{Zr}$ to $\mathrm{BaCe}_{1-x-y} \mathrm{Zr}_{y} \mathrm{Y}_{x} \mathrm{O}_{3}$ for improving the chemical stability had been reported. ${ }^{14)-16)}$ Thence, $\mathrm{BaCe}_{1-x-y} \mathrm{Zr}_{y} \mathrm{Y}_{x} \mathrm{O}_{3}$ becomes the wild-using proton conductors 
due to the good chemical stability and high protonic conductivity. Lee et al. pointed out that partially substituting $\mathrm{Ba}$ with $\mathrm{Sr}$ could improve the conductivity in $\mathrm{Ba}_{1-x} \mathrm{Sr}_{x} \mathrm{Ce}_{0.6} \mathrm{Zr}_{0.2} \mathrm{Y}_{0.2} \mathrm{O}_{3-\delta}(0.0 \leqq$ $x \leqq 0.2)$ proton conducting oxides system; the highest conductivity reaches $0.009 \mathrm{~S} / \mathrm{cm}$ at $800^{\circ} \mathrm{C} .{ }^{17)}$ The $\mathrm{Sr}$ doped $\mathrm{Ba}_{1-x} \mathrm{Sr}_{x^{-}}$ $\mathrm{Ce}_{0.6} \mathrm{Zr}_{0.2} \mathrm{Y}_{0.2} \mathrm{O}_{3-\delta}(0.0 \leqq x \leqq 1.0)$ samples, however, need to be sintered at a relatively high sintering temperature $\left(1600^{\circ} \mathrm{C}\right)$. The high sintering temperature made metal evaporates and is difficult to choose a proper supporting electrode material with enough porosity after sintering. Adding sintering aids such as $\mathrm{ZnO}$ improve the sintering ability of $\mathrm{BaCeO}_{3}$-base proton conductors and reduce sintering temperature for $100-150^{\circ} \mathrm{C}$. The sintering aids may affect the protonic conductivity of the oxide electrolytes. ${ }^{18)} \mathrm{Bi}$ et al. reported that indium doped $\mathrm{BaCe}_{0.7} \mathrm{In}_{0.3} \mathrm{O}_{3-\delta}$ enhanced the chemical stability and sintering ability of the electrolyte, membrane with a dense microstructure was obtained after being sintered at a relatively lower temperature. ${ }^{19)}$ Zhao et al. also reported that $\mathrm{BaIn}_{0.1} \mathrm{Y}_{0.2} \mathrm{Ce}_{0.7} \mathrm{O}_{3-\delta}$ has conductivity of $1.27 \times 10^{-2}, 1.33 \times 10^{-2}, 8.52 \times 10^{-3}$ and $8.7 \times 10^{-3} \mathrm{~S} / \mathrm{cm}$ in dry air, wet air, wet nitrogen, and wet hydrogen at $800^{\circ} \mathrm{C}$, respectively.

In this study, the influences of the In doping on the sintering behaviors, microstructures, proton conductivity, and chemical stabilities in $\mathrm{CO}_{2}$ atmosphere of $\mathrm{Ba}_{0.8} \mathrm{Sr}_{0.2} \mathrm{Ce}_{0.6} \mathrm{Zr}_{0.2} \mathrm{In}_{x} \mathrm{Y}_{0.2-x^{-}}$ $\mathrm{O}_{3-\delta}(0.0 \leqq x \leqq 0.2)$ electrolytes are investigated. The protonconducting oxides with compositions of $\mathrm{Ba}_{0.8} \mathrm{Sr}_{0.2} \mathrm{Ce}_{0.6} \mathrm{Zr}_{0.2} \mathrm{In}_{x^{-}}$ $\mathrm{Y}_{0.2-x} \mathrm{O}_{3-\delta}(0.0 \leqq x \leqq 0.2)$ and $\mathrm{Ba}_{0.8} \mathrm{Sr}_{0.2} \mathrm{Ce}_{0.8-x-y} \mathrm{Zr}_{y} \mathrm{In}_{x} \mathrm{Y}_{0.2} \mathrm{O}_{3-\delta}$ $(x=0.05,0.1 y=0,0.1)$ are studied in order to achieve the highest conductivity electrolyte for anode-supported half-cell. The cell performances for the anode-supported half-cells coated with Pt paste are also reported in this study.

\section{Experimental procedures}

The solid state reaction process is used for preparing $\mathrm{Ba}_{0.8} \mathrm{Sr}_{0.2^{-}}$ $\mathrm{Ce}_{0.6} \mathrm{Zr}_{0.2} \operatorname{In}_{x} \mathrm{Y}_{0.2-x} \mathrm{O}_{3-\delta}(0.0 \leqq x \leqq 0.2)$ powders. In this study, $\mathrm{BaCO}_{3}$ (Panreac Quimica, S.A.U./Spain, 98\%), $\mathrm{SrCO}_{3}$ (Panreac Quimica, S.A.U./Spain, 98\%), $\mathrm{CeO}_{2}$ (NOAH Technologies Co./ U.S.A, 99.9\%), $\mathrm{ZrO}_{2}$ (NOAH Technologies Co./U.S.A, 99.9\%), $\mathrm{Y}_{2} \mathrm{O}_{3}$ (STREM CHEMICAL/U.S.A., 99.9\%), and $\mathrm{In}_{2} \mathrm{O}_{3}$ (Alfa Aesar/U.S.A., 99.9\%) were ball-milled with isopropanol for $6 \mathrm{~h}$ and dried in an $110^{\circ} \mathrm{C}$ oven. The mixed powders were calcined at $1250^{\circ} \mathrm{C}$ for $8 \mathrm{~h}$ with a heating rate of $5^{\circ} \mathrm{C} / \mathrm{min}$, powders with pure perovskite phase were obtained. The electrolyte with compositions of $\mathrm{Ba}_{0.8} \mathrm{Sr}_{0.2} \mathrm{Ce}_{z} \mathrm{Zr}_{y} \operatorname{In}_{x} \mathrm{Y}_{0.2} \mathrm{O}_{3-\delta}(x+y+z=0.8)$ powders was also prepared as the same process of $\mathrm{Ba}_{0.8} \mathrm{Sr}_{0.2} \mathrm{Ce}_{0.6^{-}}$ $\mathrm{Zr}_{0.2} \mathrm{In}_{x} \mathrm{Y}_{0.2-x} \mathrm{O}_{3-\delta}(0.0 \leqq x \leqq 0.2)$ powder used. The calcined powders were pressed at $250 \mathrm{MPa}$ into cylindrical pellets with $12 \mathrm{~mm}$ in diameter and $1 \mathrm{~mm}$ in thickness. Then the green pellets were sintered at 1300,1350 , and $1450^{\circ} \mathrm{C}$ in air for $4 \mathrm{~h}$, with a heating rate of $5^{\circ} \mathrm{C} / \mathrm{min}$.

$\mathrm{X}$-ray diffractometer (XRD, Bruker, D8A) was used to determine the crystal structures of $\mathrm{Ba}_{0.8} \mathrm{Sr}_{0.2} \mathrm{Ce}_{0.6} \mathrm{Zr}_{0.2} \operatorname{In}_{x} \mathrm{Y}_{0.2-x} \mathrm{O}_{3-\delta}$ $(0.0 \leqq x \leqq 0.2)$ ceramics with $\mathrm{Cu} \mathrm{K}_{\alpha}$ radiation and the diffraction angles from 20 to $80^{\circ}$ with a step size of $0.07^{\circ} / \mathrm{s}$. Field-emission scanning electron microscopy (FE-SEM, FEI, Inspect F50) was used to observe the morphology and grain size of $\mathrm{Ba}_{0.8} \mathrm{Sr}_{0.2^{-}}$ $\mathrm{Ce}_{0.6} \mathrm{Zr}_{0.2} \mathrm{In}_{x} \mathrm{Y}_{0.2-x} \mathrm{O}_{3-\delta}(0.0 \leqq x \leqq 0.2)$ ceramics. Thermal dilatometer analysis (TDA, Setaram Setsys Evolution) was conducted to investigate the thermal shrinkage of $\mathrm{Ba}_{0.8} \mathrm{Sr}_{0.2} \mathrm{Ce}_{0.6^{-}}$ $\mathrm{Zr}_{0.2} \mathrm{In}_{x} \mathrm{Y}_{0.2-x} \mathrm{O}_{3-\delta}(0.0 \leqq x \leqq 0.2)$ ceramics with different In doping contents heat-treated from room temperature to $1600^{\circ} \mathrm{C}$ with heating rate of $10^{\circ} \mathrm{C} / \mathrm{min}$. The linear shrinkage of the $\mathrm{Ba}_{0.8} \mathrm{Sr}_{0.2} \mathrm{Ce}_{0.6} \mathrm{Zr}_{0.2} \mathrm{In}_{x} \mathrm{Y}_{0.2-x} \mathrm{O}_{3-\delta} \quad(0.0 \leqq x \leqq 0.2)$ system were measured. The shrinkages of the sintering ceramics were calculated by using Eq. (1):

$$
S(\%)=\frac{D_{b}-D_{a}}{D_{b}} \times 100 \%
$$

Where $S$ is the shrinkage of the pellet, $D_{b}$ is the diameter of the pellet before sintering and $D_{a}$ is the diameter of the pellet after sintering.

The chemical stability of the $\mathrm{Ba}_{0.8} \mathrm{Sr}_{0.2} \mathrm{Ce}_{0.6} \mathrm{Zr}_{0.2} \mathrm{In}_{x} \mathrm{Y}_{0.2-x} \mathrm{O}_{3-\delta}$ $(0.0 \leqq x \leqq 0.2)$ ceramics was evaluated by exposing ceramics to $600^{\circ} \mathrm{C}$ in $\mathrm{CO}_{2}(99.99 \%)$ atmosphere for 4 and $8 \mathrm{~h}$. After stability test, the crystal structures of sintered samples were re-examined by using the X-ray Diffractometer to determine phase change of the test samples. The conductivity of the sintered ceramics was measured by using a DC two-probe method in hydrogen from room temperature to $800^{\circ} \mathrm{C}$. Silver paste was painted on both sides of the sintered ceramics as current collectors. The resistivities of the sintered pellets were acquired using an Agilent 34970 A meter. The conductivity of ceramics was calculated by using Eq. (2):

$$
\sigma=\frac{L}{R \times A}
$$

Where $\sigma$ is the conductivity $(\mathrm{S} / \mathrm{cm})$ of the pellet, $L$ is the thickness $(\mathrm{cm})$ of the pellet, $A$ is the area $\left(\mathrm{cm}^{2}\right)$ of the electrode, and $R$ is the electrical resistance $(\Omega)$ of the pellet.

The anode supported half-cell with electrolyte was prepared using a tape casting process. The mixture of NiO (SHOWA/ Japan, 99.8\%) and $\mathrm{Ba}_{0.8} \mathrm{Sr}_{0.2} \mathrm{Ce}_{0.6} \mathrm{Zr}_{0.2} \mathrm{Y}_{0.2} \mathrm{O}_{3-\delta}$ (BSCZY) with weight ratio of $65: 35$ was used as anode material, the powders were ball-milled in isopropanol for $24 \mathrm{~h}$ to achieve a homogeneous state. After ball milling $24 \mathrm{~h}$, another $30 \mathrm{wt} \%$ starch (Panreac Quimica, S.A.U./E.U.) was added into the mixture of anode material as pore former to produce sufficiently porosity. Then the electrolyte $\left(\mathrm{Ba}_{0.8} \mathrm{Sr}_{0.2} \mathrm{Ce}_{0.65} \mathrm{In}_{0.05} \mathrm{Y}_{0.2} \mathrm{O}_{3-\delta}\right)$ and anode (NiO-BSCZY) powders were mixed with dispersant and binders (polyvinyl butyral) by ball milling in polyethylene jar for $12 \mathrm{~h}$. The mixed slurry was degased under vacuum and tape casted onto a Mylar carrier to obtain green sheets with dry thickness of about $120 \mu \mathrm{m}$. The green tapes of electrolyte and anode material were laminated and cut into cylindrical with $35 \mathrm{~mm}$ in diameter. The laminated green tapes were then sintered in air at $1450^{\circ} \mathrm{C}$ for $4 \mathrm{~h}$. Then the sintered anode-supported half-cell was coated with Pt paste as cathode for I-V curve performance testing. The fuel cell measurement was tested on a self-designed fuel cell test station. The fuel cell was sealed on an alumina tube, fixed by a glass ring. For the fuel cell tests, Pt wires were mounted with $\mathrm{Pt}$ paste on the top of the anode and cathode to act as current collectors. The anode side of NiO-BSCZY was exposed to pure hydrogen gas, and the cathode side of Pt was exposed to air. The fuel cell tests were performed in a temperature range of 550$800^{\circ} \mathrm{C}$. The area of cell electrode was $4.3 \mathrm{~cm}^{2}$ and the flow rate of the fuel gas was about $90 \mathrm{ml} \mathrm{min}^{-1}$.

\section{Results and discussion}

Figure 1 shows the XRD patterns of $\mathrm{Ba}_{0.8} \mathrm{Sr}_{0.2} \mathrm{Ce}_{0.6} \mathrm{Zr}_{0.2} \mathrm{In}_{x^{-}}$ $\mathrm{Y}_{0.2-x} \mathrm{O}_{3-\delta}(0.0 \leqq x \leqq 0.2)$ ceramics sintered at $1450^{\circ} \mathrm{C}$ for $4 \mathrm{~h}$. All the samples show a perovskite-type cubic structure. The peaks match the characteristic diffraction of $\mathrm{BaCeO}_{3}$ (JCPDS 750431), showing seven diffraction signals, namely (100), (110), (200), (211), (220), (310), (222) planes. There did not have any second phases found, which indicates that $\mathrm{Ba}_{0.8} \mathrm{Sr}_{0.2} \mathrm{Ce}_{0.6} \mathrm{Zr}_{0.2} \mathrm{In}_{x^{-}}$ $\mathrm{Y}_{0.2-x} \mathrm{O}_{3-\delta}(0.0 \leqq x \leqq 0.2)$ single-phase is successfully synthe- 


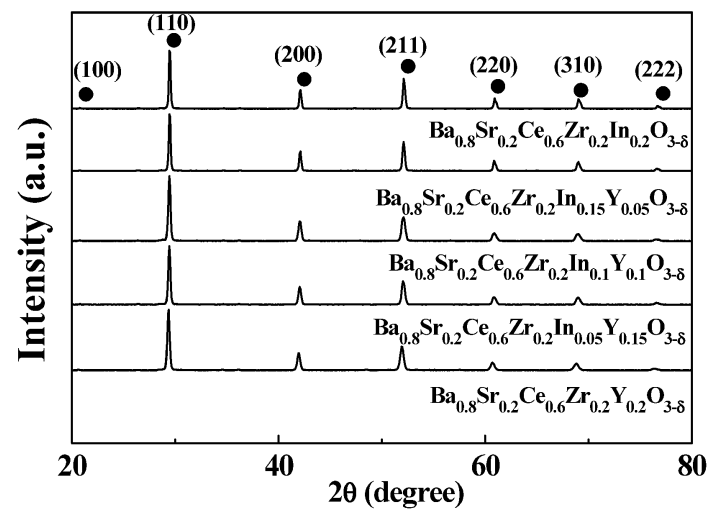

Fig. 1. X-ray Diffraction patterns of $\mathrm{Ba}_{0.8} \mathrm{Sr}_{0.2} \mathrm{Ce}_{0.6} \mathrm{Zr}_{0.2} \mathrm{In}_{x} \mathrm{Y}_{0.2-x} \mathrm{O}_{3-\delta}$ $(0.0 \leqq x \leqq 0.2)$ ceramics sintered at $1450^{\circ} \mathrm{C}$ for $4 \mathrm{~h}$.

Table 1. Unit Cell Parameter and tolerance factor of the $\mathrm{Ba}_{0.8} \mathrm{Sr}_{0.2}$ $\mathrm{Ce}_{0.6} \mathrm{Zr}_{0.2} \mathrm{In}_{x} \mathrm{Y}_{0.2-x} \mathrm{O}_{3-\delta} \quad(0.0 \leqq x \leqq 0.2) \quad$ oxides ceramics sintered at $1450^{\circ} \mathrm{C}$ for $4 \mathrm{~h}$.

\begin{tabular}{|c|c|c|c|c|}
\hline \multirow{2}{*}{$\begin{array}{c}\mathrm{Ba}_{0.8} \mathrm{Sr}_{0.2} \mathrm{Ce}_{0.6} \mathrm{Zr}_{0.2} \mathrm{In}_{x} \mathrm{Y}_{0.2-x} \mathrm{O}_{3-\delta} \\
(0.0 \leqq x \leqq 0.2)\end{array}$} & \multicolumn{2}{|c|}{$\begin{array}{l}\text { Unit Cell } \\
\text { Parameter }\end{array}$} & \multicolumn{2}{|c|}{$\begin{array}{l}\text { Tolerance } \\
\text { factor }\end{array}$} \\
\hline & $\begin{array}{c}\mathrm{a} \\
(\AA)\end{array}$ & $\begin{array}{c}\text { Volume } \\
\left(\AA^{3}\right)\end{array}$ & $\begin{array}{c}\mathrm{r}_{\mathrm{B}} \\
(\AA)\end{array}$ & $\mathrm{t}$ \\
\hline 0 & 4.2997 & 79.49 & 0.846 & 0.855 \\
\hline 0.05 & 4.2893 & 78.91 & 0.841 & 0.857 \\
\hline 0.1 & 4.2884 & 78.87 & 0.836 & 0.859 \\
\hline 0.15 & 4.2855 & 78.71 & 0.831 & 0.860 \\
\hline 0.2 & 4.2847 & 78.66 & 0.826 & 0.86 \\
\hline
\end{tabular}

$t=\frac{r_{A}+r_{O}}{\sqrt{2}\left(r_{B}+r_{O}\right)}, r_{B}$ : The ion radius of the B-site, t: Tolerance factor.

sized using the solid state reaction method and the ceramics are identical in essential to the report by Lee et al. ${ }^{17)}$ The X-ray diffraction angles of $\mathrm{Ba}_{0.8} \mathrm{Sr}_{0.2} \mathrm{Ce}_{0.6} \mathrm{Zr}_{0.2} \mathrm{In}_{x} \mathrm{Y}_{0.2-x} \mathrm{O}_{3-\delta}(0.0 \leqq x \leqq$ $0.2)$ perovskite shifted to higher angles with increasing the In doping contents,it is consistent with the investigation reported by Giannici et al. ${ }^{20)}$ Due to ion radius difference of $\operatorname{In}^{3+}(0.80 \AA)$ and $\mathrm{Y}^{3+}(0.92 \AA)$ ion, lattice parameters and cell volumes of of $\mathrm{Ba}_{0.8} \mathrm{Sr}_{0.2} \mathrm{Ce}_{0.6} \mathrm{Zr}_{0.2} \mathrm{In}_{x} \mathrm{Y}_{0.2-x} \mathrm{O}_{3-\delta}(0.0 \leqq x \leqq 0.2)$ ceramics show nearly linear decreasing trend with increasing In doping contents, which is consistent with Vegard's law, as listed in Table 1. Increasing the smaller ion radius of $\mathrm{In}^{3+}$ to replace the $\mathrm{Y}^{3+}$ ion, the lattice sizes shrunk accordingly, and the structure became less distortion. ${ }^{17), 21)}$

TDA results of the $\mathrm{Ba}_{0.8} \mathrm{Sr}_{0.2} \mathrm{Ce}_{0.6} \mathrm{Zr}_{0.2} \mathrm{In}_{x} \mathrm{Y}_{0.2-x} \mathrm{O}_{3-\delta}(0.0 \leqq$ $x \leqq 0.2)$ ceramics are shown in Fig. 2 . The $\mathrm{Ba}_{0.8} \mathrm{Sr}_{0.2} \mathrm{Ce}_{0.6} \mathrm{Zr}_{0.2^{-}}$ $\mathrm{Y}_{0.2} \mathrm{O}_{3-\delta}$ perovskite starts to shrink at temperature of $1400^{\circ} \mathrm{C}$, which indicates that the initial sintering occurs at this temperature. However, initial sintering stages of $\mathrm{Ba}_{0.8} \mathrm{Sr}_{0.2} \mathrm{Ce}_{0.6} \mathrm{Zr}_{0.2^{-}}$ $\mathrm{In}_{0.05} \mathrm{Y}_{0.15} \mathrm{O}_{3-\delta}$ and $\mathrm{Ba}_{0.8} \mathrm{Sr}_{0.2} \mathrm{Ce}_{0.6} \mathrm{Zr}_{0.2} \mathrm{In}_{0.2} \mathrm{O}_{3-\delta}$ are at temperature about $1200^{\circ} \mathrm{C}$. $\mathrm{Ba}_{0.8} \mathrm{Sr}_{0.2} \mathrm{Ce}_{0.6} \mathrm{Zr}_{0.2} \mathrm{Y}_{0.2} \mathrm{O}_{3-\delta}$ oxide ceramic presents the smallest shrinkage of $6.96 \%$, the In-doped samples have larger shrinkage of 14.32 and $11.82 \%$ for the composition of $\mathrm{Ba}_{0.8} \mathrm{Sr}_{0.2} \mathrm{Ce}_{0.6} \mathrm{Zr}_{0.2} \mathrm{In}_{0.05} \mathrm{Y}_{0.15} \mathrm{O}_{3-\delta}$ and $\mathrm{Ba}_{0.8} \mathrm{Sr}_{0.2} \mathrm{Ce}_{0.6} \mathrm{Zr}_{0.2^{-}}$ $\mathrm{In}_{0.2} \mathrm{O}_{3-\delta}$, respectively. This indicates that the sinterability of $\mathrm{Ba}_{0.8} \mathrm{Sr}_{0.2} \mathrm{Ce}_{0.6} \mathrm{Zr}_{0.2} \mathrm{In}_{x} \mathrm{Y}_{0.2-x} \mathrm{O}_{3-\delta} \quad(0.0 \leqq x \leqq 0.2)$ ceramics was significantly improved by In doping, the $\mathrm{Ba}_{0.8} \mathrm{Sr}_{0.2} \mathrm{Ce}_{0.6} \mathrm{Zr}_{0.2} \mathrm{In}_{x^{-}}$ $\mathrm{Y}_{0.2-x} \mathrm{O}_{3-\delta}(0.0 \leqq x \leqq 0.2)$ ceramics can be densified at the lower temperature by doping 0.05 at $\%$ indium.

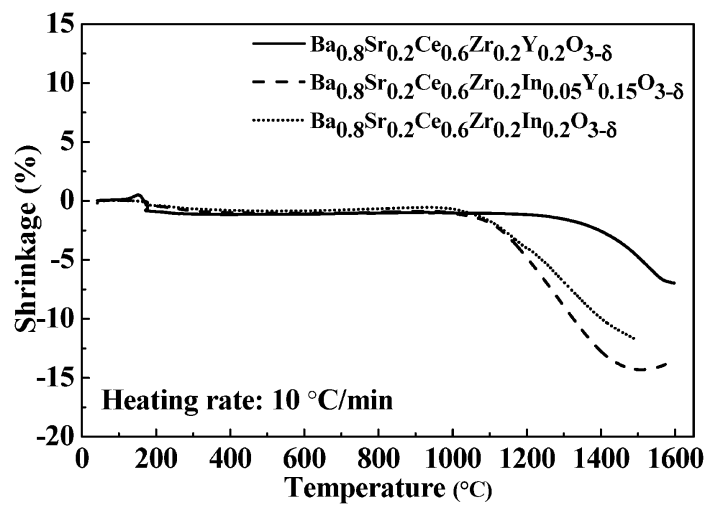

Fig. 2. Linear shrinkage of $\mathrm{Ba}_{0.8} \mathrm{Sr}_{0.2} \mathrm{Ce}_{0.6} \mathrm{Zr}_{0.2} \mathrm{In}_{x} \mathrm{Y}_{0.2-x} \mathrm{O}_{3-\delta} \quad(0.0 \leqq$ $x \leqq 0.2$ ) ceramics compact during heat-treatment, heating rate was $10^{\circ} \mathrm{C} / \mathrm{min}$.

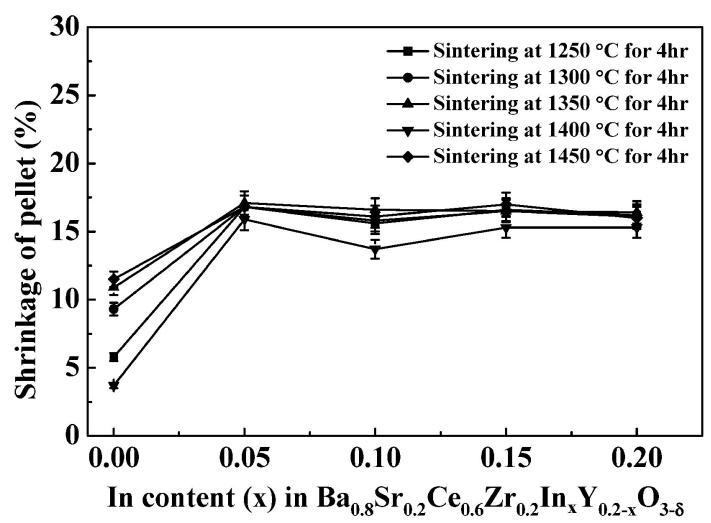

Fig. 3. Shrinkages of $\mathrm{Ba}_{0.8} \mathrm{Sr}_{0.2} \mathrm{Ce}_{0.6} \mathrm{Zr}_{0.2} \mathrm{In}_{x} \mathrm{Y}_{0.2-x} \mathrm{O}_{3-\delta}(0.0 \leqq x \leqq 0.2)$ ceramics sintered at different conditions.

The shrinkage of $\mathrm{Ba}_{0.8} \mathrm{Sr}_{0.2} \mathrm{Ce}_{0.6} \mathrm{Zr}_{0.2} \mathrm{In}_{x} \mathrm{Y}_{0.2-x} \mathrm{O}_{3-\delta}(0.0 \leqq x \leqq$ $0.2)$ system at different sintering conditions are shown in Fig. $\mathbf{3}$. The $\mathrm{Ba}_{0.8} \mathrm{Sr}_{0.2} \mathrm{Ce}_{0.6} \mathrm{Zr}_{0.2} \mathrm{Y}_{0.2} \mathrm{O}_{3-\delta}$ ceramic without In doping content had shrinkage of $3.7,5.8,9.3,11.5$, and $10.9 \%$ when the samples were sintered at the temperature of 1250,1300 , 1350,1400 , and $1450^{\circ} \mathrm{C}$ for $4 \mathrm{~h}$, respectively. The shrinkage of $\mathrm{Ba}_{0.8} \mathrm{Sr}_{0.2} \mathrm{Ce}_{0.6} \mathrm{Zr}_{0.2} \mathrm{In}_{0.05} \mathrm{Y}_{0.15} \mathrm{O}_{3-\delta}$ pellet were 15.9, 16.8, 16.8, 16.8 , and $17.1 \%$ after sintered at the same sintering condition as $\mathrm{Ba}_{0.8} \mathrm{Sr}_{0.2} \mathrm{Ce}_{0.6} \mathrm{Zr}_{0.2} \mathrm{Y}_{0.2-x} \mathrm{O}_{3-\delta}$ ceramic. However, when the ceramics with doping more than 0.05 at $\%$ indium content sintered at the temperature of $1250,1300,1350,1400$, and $1450^{\circ} \mathrm{C}$ for $4 \mathrm{~h}$, all of the $\mathrm{Ba}_{0.8} \mathrm{Sr}_{0.2} \mathrm{Ce}_{0.6} \mathrm{Zr}_{0.2} \operatorname{In}_{x} \mathrm{Y}_{0.2-x} \mathrm{O}_{3-\delta}(0.0 \leqq x \leqq 0.2)$ ceramics exhibits almost consistent shrinkages which was about $15-17 \%$ except for the $\mathrm{Ba}_{0.8} \mathrm{Sr}_{0.2} \mathrm{Ce}_{0.6} \mathrm{Zr}_{0.2} \mathrm{Y}_{0.2} \mathrm{O}_{3-\delta}$ pellet. This implied that the ceramics doping more than 0.05 at $\%$ indium content can reached their significant effect on decreasing sintering temperature. Besides, similar benefits on the sintering of $\mathrm{BaCeO}_{3}$-based oxides by doping In contents were also reported in literatures. ${ }^{22)}$

The fracture surface morphologies of the $\mathrm{Ba}_{0.8} \mathrm{Sr}_{0.2} \mathrm{Ce}_{0.6} \mathrm{Zr}_{0.2^{-}}$ $\operatorname{In}_{x} \mathrm{Y}_{0.2-x} \mathrm{O}_{3-\delta}(0.0 \leqq x \leqq 0.2)$ ceramic pellets sintered at $1450^{\circ} \mathrm{C}$ for $4 \mathrm{~h}$ are shown in Fig. 4. The microstructure with many pores in the grains was observed on fracture surface of the $\mathrm{Ba}_{0.8} \mathrm{Sr}_{0.2^{-}}$ $\mathrm{Ce}_{0.6} \mathrm{Zr}_{0.2} \mathrm{Y}_{0.2} \mathrm{O}_{3-\delta}$ ceramic sintered at $1450^{\circ} \mathrm{C}$. Conversely, the pore density decreasing significantly with In contents, when it is more than 0.05 at \%, a dense and uniform grain size microstructure of the $\mathrm{Ba}_{0.8} \mathrm{Sr}_{0.2} \mathrm{Ce}_{0.6} \mathrm{Zr}_{0.2} \mathrm{In}_{x} \mathrm{Y}_{0.2-x} \mathrm{O}_{3-\delta}(0.0 \leqq x \leqq 0.2)$ ceramic pellets can be obtained. Accordingly, the $\mathrm{Ba}_{0.8} \mathrm{Sr}_{0.2^{-}}$ $\mathrm{Ce}_{0.6} \mathrm{Zr}_{0.2} \mathrm{In}_{x} \mathrm{Y}_{0.2-x} \mathrm{O}_{3-\delta} \quad(0.0 \leqq x \leqq 0.2) \quad$ ceramics with good 

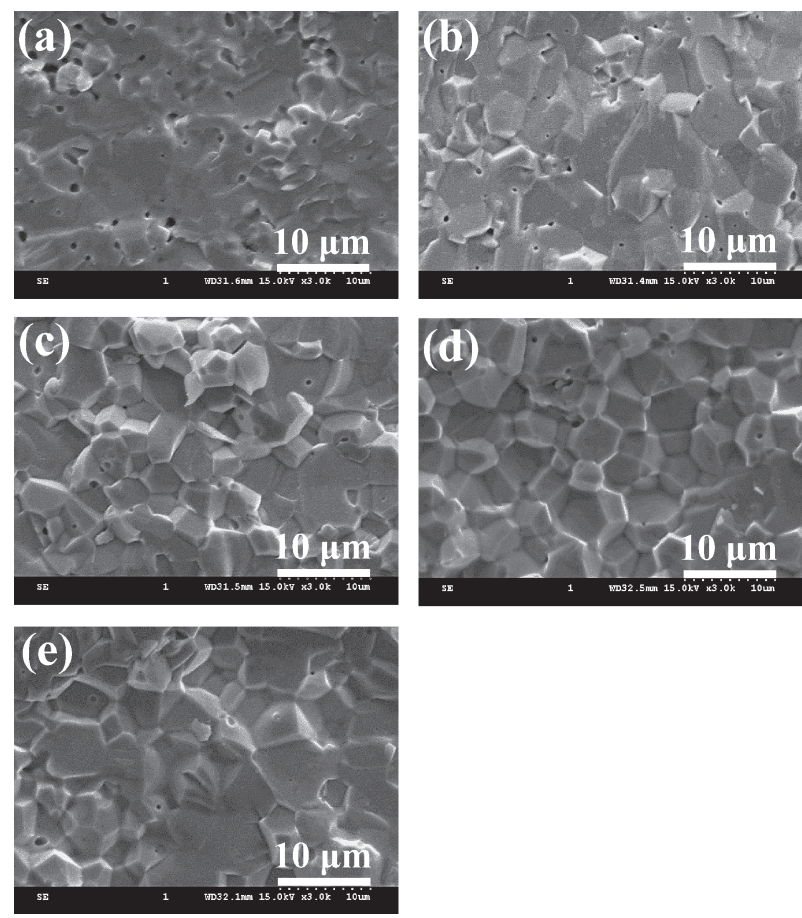

Fig. 4. Fracture morphologies of the $\mathrm{Ba}_{0.8} \mathrm{Sr}_{0.2} \mathrm{Ce}_{0.6} \mathrm{Zr}_{0.2} \mathrm{In}_{x} \mathrm{Y}_{0.2-x} \mathrm{O}_{3-\delta}$ $(0.0 \leqq x \leqq 0.2)$ ceramic pellets, (a) $x=0$, (b) $x=0.05$, (c) $x=0.1$, (d) $x=0.15$, and (e) $x=0.2$. The samples were sintered at $1450^{\circ} \mathrm{C}$ for $4 \mathrm{~h}$.

sinterability is suggested to be a potential electrolyte material for $\mathrm{P}^{+}$-SOFC applications.

The chemical stability of In doping sintered ceramics were in the $\mathrm{CO}_{2}$ atmosphere was investigated by XRD. Figure 5 shows the XRD patterns of $\mathrm{Ba}_{0.8} \mathrm{Sr}_{0.2} \mathrm{Ce}_{0.6} \mathrm{Zr}_{0.2} \mathrm{In}_{x} \mathrm{Y}_{0.2-x} \mathrm{O}_{3-\delta}(0.0 \leqq x \leqq$ 0.2) ceramics exposed to a $\mathrm{CO}_{2}$ atmosphere at $600^{\circ} \mathrm{C}$ for 4 and $8 \mathrm{~h}$, respectively. The $\mathrm{Ba}_{0.8} \mathrm{Sr}_{0.2} \mathrm{Ce}_{0.6} \mathrm{Zr}_{0.2} \operatorname{In}_{x} \mathrm{Y}_{0.2-x} \mathrm{O}_{3-\delta}(0.0 \leqq x \leqq$ 0.2) samples were slightly decomposed into $\mathrm{BaCO}_{3}$ and $\mathrm{CeO}_{2}$. The reactions between $\mathrm{BaCeO}_{3}$ and $\mathrm{CO}_{2}$ are occurring as Eq. (3).

$$
\mathrm{BaCeO}_{3}+\mathrm{CO}_{2} \rightarrow \mathrm{BaCO}_{3}+\mathrm{CeO}_{2}
$$

Although the (111), (112), (113) planes of $\mathrm{BaCO}_{3}$ phase and (311) plane of $\mathrm{CeO}_{2}$ phase present when the $\mathrm{Ba}_{0.8} \mathrm{Sr}_{0.2} \mathrm{Ce}_{0.6} \mathrm{Zr}_{0.2^{-}}$ $\mathrm{In}_{x} \mathrm{Y}_{0.2-x} \mathrm{O}_{3-\delta}(0.0 \leqq x \leqq 0.2)$ samples exposed to a $\mathrm{CO}_{2}$ atmosphere for $8 \mathrm{~h}$, the intensity ratio of those phases to the main phase decreased significantly with increasing In doping contents. This indicates that the $\mathrm{Ba}_{0.8} \mathrm{Sr}_{0.2} \mathrm{Ce}_{0.6} \mathrm{Zr}_{0.2} \mathrm{In}_{x} \mathrm{Y}_{0.2-x} \mathrm{O}_{3-\delta} \quad(0.0 \leqq x \leqq$ 0.2 ) system with a small amount of In actually improve the ceramics to resist $\mathrm{CO}_{2}$ atmosphere.

In order to realize the effect of In doping on the structure stability, the distortion of cubic lattice was calculated based on the Goldschmidt tolerance factor, as shown in Eq. (4):23)

$$
t=\frac{r_{A}+r_{O}}{\sqrt{2}\left(r_{B}+r_{O}\right)}
$$

Where $t$ is the tolerance factor, $r_{A}$ is the ion radius of the A-site, $r_{B}$ is the ion radius of the $B$-site, and $r_{O}$ is the ion radius of oxygen.

The ion radius of $\mathrm{Ba}^{2+}(1.35 \AA), \mathrm{Sr}^{2+}(1.18 \AA), \mathrm{Ce}^{4+}(0.87 \AA)$, $\mathrm{Zr}^{4+}(0.72 \AA), \mathrm{Y}^{3+}(0.9 \AA), \mathrm{In}^{3+}(0.8 \AA)$ and $\mathrm{O}^{2-}(1.40 \AA)$ were applied to calculate the tolerance by Goldschmidt definition and listed in Table 1. It is implies that the tolerance factor increasing with In doping contents. Bhide et al. ${ }^{24)}$ proposed that the
(A)

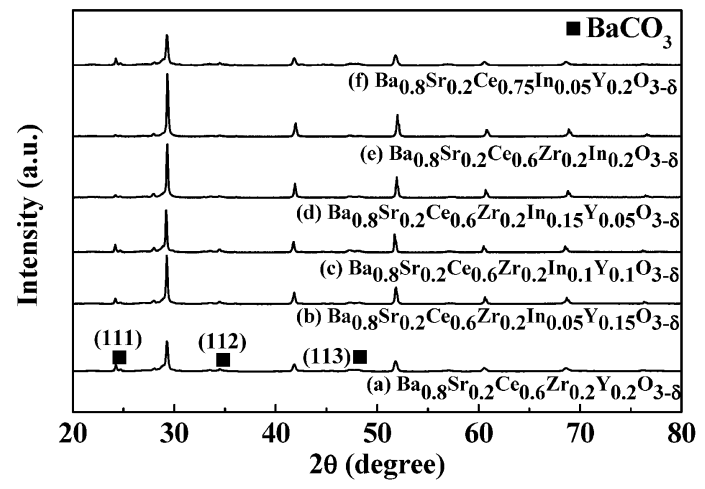

(B)

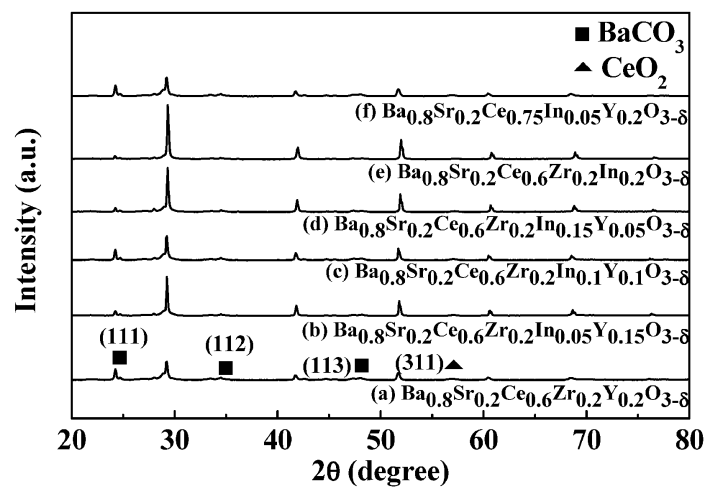

Fig. 5. X-ray Diffraction patterns of (a) $\mathrm{Ba}_{0.8} \mathrm{Sr}_{0.2} \mathrm{Ce}_{0.6} \mathrm{Zr}_{0.2} \mathrm{Y}_{0.2} \mathrm{O}_{3-\delta}$ (b) $\mathrm{Ba}_{0.8} \mathrm{Sr}_{0.2} \mathrm{Ce}_{0.6} \mathrm{Zr}_{0.2} \mathrm{In}_{0.05} \mathrm{Y}_{0.15} \mathrm{O}_{3-\delta}$ (c) $\mathrm{Ba}_{0.8} \mathrm{Sr}_{0.2} \mathrm{Ce}_{0.6} \mathrm{Zr}_{0.2} \mathrm{In}_{0.1} \mathrm{Y}_{0.1} \mathrm{O}_{3-\delta}$ (d) $\mathrm{Ba}_{0.8} \mathrm{Sr}_{0.2} \mathrm{Ce}_{0.6} \mathrm{Zr}_{0.2} \mathrm{In}_{0.15} \mathrm{Y}_{0.05} \mathrm{O}_{3-\delta}$ (e) $\mathrm{Ba}_{0.8} \mathrm{Sr}_{0.2} \mathrm{Ce}_{0.6} \mathrm{Zr}_{0.2} \mathrm{In}_{0.2} \mathrm{O}_{3-\delta}$ (f) $\mathrm{Ba}_{0.8} \mathrm{Sr}_{0.2} \mathrm{Ce}_{0.75} \mathrm{In}_{0.05} \mathrm{Y}_{0.2} \mathrm{O}_{3-\delta}$ ceramics exposed to a $\mathrm{CO}_{2}$ atmosphere at $600^{\circ} \mathrm{C}$ for (A) $4 \mathrm{~h}$ and (B) $8 \mathrm{~h}$.

closer the tolerance factor to unity ( $\mathrm{t}$ closer to 1 ), the greater the expected stability of the perovskite-type structure. Since the ion radius of $\mathrm{In}^{3+}$ is much smaller than the ion radius of $\mathrm{Ce}^{4+}$ and $\mathrm{Y}^{3+}$, the tolerance factor would increase with the doped $\mathrm{In}^{3+}$ concentration and the binding energy become stronger between the $\mathrm{B}$-site ion and the oxygen ion. As a result, the chemical stability to against $\mathrm{CO}_{2}$ atmosphere of $\mathrm{Ba}_{0.8} \mathrm{Sr}_{0.2} \mathrm{Ce}_{0.6} \mathrm{Zr}_{0.2} \mathrm{In}_{x} \mathrm{Y}_{0.2-x} \mathrm{O}_{3-\delta}$ $(0.0 \leqq x \leqq 0.2)$ system will be enhanced by In doping. $\left.{ }^{25}\right)$

Due to the poor conductivity of $\mathrm{Ba}_{0.8} \mathrm{Sr}_{0.2} \mathrm{Ce}_{0.6} \mathrm{Zr}_{0.2} \operatorname{In}_{x} \mathrm{Y}_{0.2-x^{-}}$ $\mathrm{O}_{3-\delta}(0.0 \leqq x \leqq 0.2)$ ceramics in the $\mathrm{H}_{2}$ atmosphere, we try to fine tune the composition $\mathrm{Ba}_{0.8} \mathrm{Sr}_{0.2} \mathrm{Ce}_{0.8-x-y} \mathrm{Zr}_{y} \mathrm{In}_{x} \mathrm{Y}_{0.2} \mathrm{O}_{3-\delta}(x=$ $0.05,0.1 y=0,0.1)$ by adjusting the composition combination among the $\mathrm{Ce}, \mathrm{Zr}$, and $\mathrm{Y}$ elements. The conductivity of $\mathrm{Ba}_{0.8} \mathrm{Sr}_{0.2} \mathrm{Ce}_{0.8-x-y} \mathrm{Zr}_{y} \mathrm{In}_{x} \mathrm{Y}_{0.2} \mathrm{O}_{3-\delta}(x=0.05,0.1 ; y=0,0.1)$ ceramics increases with increasing temperature. The $\mathrm{Ba}_{0.8} \mathrm{Sr}_{0.2^{-}}$ $\mathrm{Ce}_{0.75} \mathrm{In}_{0.05} \mathrm{Y}_{0.2} \mathrm{O}_{3-\delta}$ ceramic exhibits the highest conductivity of $0.011 \mathrm{~S} / \mathrm{cm}$ at $800^{\circ} \mathrm{C}$. This also can be explained by the change of activation energy of proton conducting in $\mathrm{Ba}_{0.8} \mathrm{Sr}_{0.2} \mathrm{Ce}_{0.8-x-y^{-}}$ $\mathrm{Zr}_{y} \mathrm{In}_{x} \mathrm{Y}_{0.2} \mathrm{O}_{3-\delta}(x=0.05,0.1 y=0,0.1)$ ceramics. The activation energy $(\mathrm{Ea})$ can be calculated by the Arrhenius equation as shown in Eq. (5).

$$
\sigma=\sigma_{0} \exp \frac{-E}{R T}
$$

According to the Arrhenius plots for $\mathrm{Ba}_{0.8} \mathrm{Sr}_{0.2} \mathrm{Ce}_{0.8-x-y} \mathrm{Zr}_{y^{-}}$ $\operatorname{In}_{x} \mathrm{Y}_{0.2} \mathrm{O}_{3-\delta}(x=0.05,0.1 y=0,0.1)$ samples tested in a $\mathrm{H}_{2}$ atmosphere as shown in Fig. 6. The slope can be used to obtain 


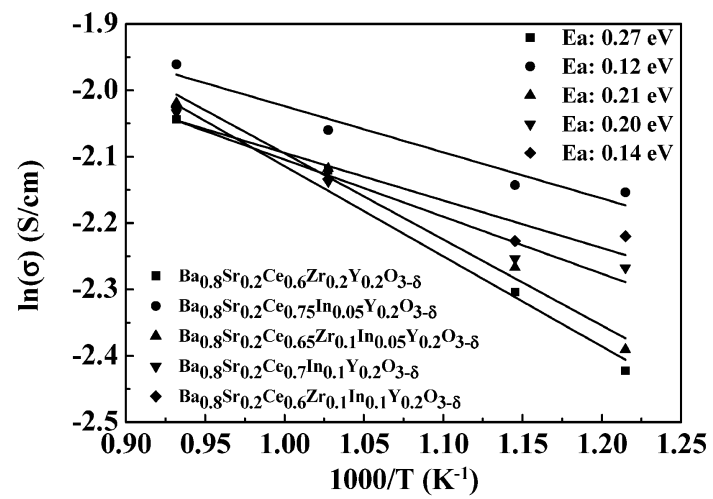

Fig. 6. Arrhenius plots for $\mathrm{Ba}_{0.8} \mathrm{Sr}_{0.2} \mathrm{Ce}_{0.8-x y} \mathrm{Zr}_{y} \mathrm{In}_{x} \mathrm{Y}_{0.2} \mathrm{O}_{3-\delta}(x=0.05$, $0.1 y=0,0.1)$ samples tested in a $\mathrm{H}_{2}$ atmosphere.

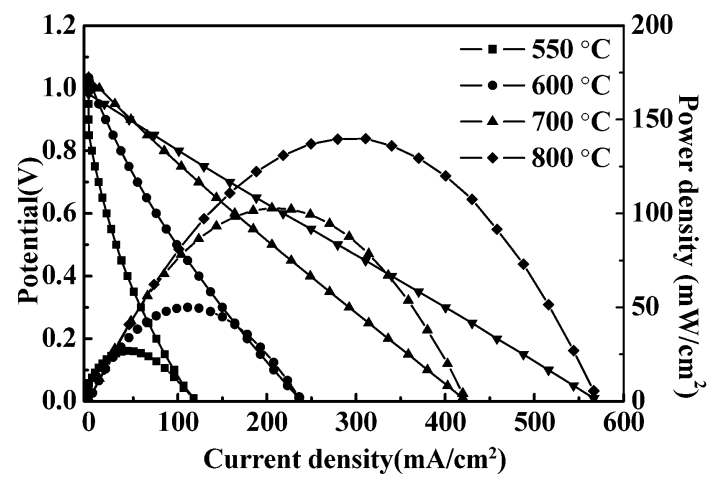

Fig. 7. Cell voltage and power density of $\mathrm{Pt} / \mathrm{Ba}_{0.8} \mathrm{Sr}_{0.2} \mathrm{Ce}_{0.75} \mathrm{In}_{0.05^{-}}$ $\mathrm{Y}_{0.2} \mathrm{O}_{3-\delta} / \mathrm{NiO}-\mathrm{Ba}_{0.8} \mathrm{Sr}_{0.2} \mathrm{Ce}_{0.6} \mathrm{Zr}_{0.2} \mathrm{Y}_{0.2} \mathrm{O}_{3-\delta}$ single cells as a function of current density for the cells based on measured in the temperature of $550-800^{\circ} \mathrm{C}$.

the activation energy by plotting $\ln (\sigma)$ as a function of $1 / \mathrm{T}$. The activation energies of the $\mathrm{Ba}_{0.8} \mathrm{Sr}_{0.2} \mathrm{Ce}_{0.75} \mathrm{In}_{0.05} \mathrm{Y}_{0.2} \mathrm{O}_{3-\delta}$ in $\mathrm{H}_{2}$ containing atmosphere was $0.12 \mathrm{eV}$, which was smaller than 0.2 and $0.27 \mathrm{eV}$ for others samples of $\mathrm{Ba}_{0.8} \mathrm{Sr}_{0.2} \mathrm{Ce}_{0.8-x-y} \mathrm{Zr}_{y} \mathrm{In}_{x} \mathrm{Y}_{0.2^{-}}$ $\mathrm{O}_{3-\delta}(x=0.05,0.1 y=0,0.1)$ and the $\mathrm{Ba}_{0.8} \mathrm{Sr}_{0.2} \mathrm{Ce}_{0.6} \mathrm{Zr}_{0.2} \mathrm{Y}_{0.2^{-}}$ $\mathrm{O}_{3-\delta}$ samples, respectively. This suggested that $\mathrm{Ba}_{0.8} \mathrm{Sr}_{0.2} \mathrm{Ce}_{0.75^{-}}$ $\operatorname{In}_{0.05} \mathrm{Y}_{0.2} \mathrm{O}_{3-\delta}$ oxide possess the highest conductivity due to its lowest activation energy for proton conducting in the $\mathrm{Ba}_{0.8} \mathrm{Sr}_{0.2^{-}}$ $\mathrm{Ce}_{0.8-x-y} \mathrm{Zr}_{y} \operatorname{In}_{x} \mathrm{Y}_{0.2} \mathrm{O}_{3-\delta}(x=0.05,0.1 y=0,0.1)$ oxides. This is in good agreement with the results of Zhang's ${ }^{26)}$ report, the conductivity of $\mathrm{BaCe}_{0.8-x} \mathrm{Ln}_{0.2} \mathrm{In}_{x} \mathrm{O}_{3-\delta}$ and $\mathrm{BaCe}_{0.8-x} \mathrm{Sm}_{0.2} \mathrm{In}_{x} \mathrm{O}_{3-\delta}$ decreased with increasing In doping. Besides, the chemical stability of the $\mathrm{Ba}_{0.8} \mathrm{Sr}_{0.2} \mathrm{Ce}_{0.75} \mathrm{In}_{0.05} \mathrm{Y}_{0.2} \mathrm{O}_{3-\delta}$ oxides to resist $\mathrm{CO}_{2}$ at $600{ }^{\circ} \mathrm{C}$ is slightly improved by doping 0.05 at $\%$ indium as shown in Fig. 5. As the consequence, the $\mathrm{Ba}_{0.8} \mathrm{Sr}_{0.2} \mathrm{Ce}_{0.75} \mathrm{In}_{0.05^{-}}$ $\mathrm{Y}_{0.2} \mathrm{O}_{3-\delta}$ is a potential electrolyte for fabricating the anode supported single cell.

Figure 7 shows the results of I-V curve performance test. The cell voltage and power density as a function of current density for the cells based on $\mathrm{Pt} / \mathrm{Ba}_{0.8} \mathrm{Sr}_{0.2} \mathrm{Ce}_{0.75} \mathrm{In}_{0.05} \mathrm{Y}_{0.2} \mathrm{O}_{3-\delta} / \mathrm{NiO}-$ $\mathrm{Ba}_{0.8} \mathrm{Sr}_{0.2} \mathrm{Ce}_{0.6} \mathrm{Zr}_{0.2} \mathrm{Y}_{0.2} \mathrm{O}_{3-\delta}$ single cells measured at different temperature. The open circuit voltages $(\mathrm{OCV})$ of 1.006, 1.034, 1.035 , and $0.982 \mathrm{~V}$ are measured at $550,600,700$, and $800^{\circ} \mathrm{C}$, respectively, which indicates no gas leakages from the dense membrane of $\mathrm{Ba}_{0.8} \mathrm{Sr}_{0.2} \mathrm{Ce}_{0.75} \mathrm{In}_{0.05} \mathrm{Y}_{0.2} \mathrm{O}_{3-\delta}$ electrolyte. The maximum power densities were $26.8,50.0,102.8$, and $139.8 \mathrm{~mW} / \mathrm{cm}^{2}$ at $550,600,700$, and $800^{\circ} \mathrm{C}$, respectively. Due to the symmetric structure of laminates and similar thermal expansion coefficients,

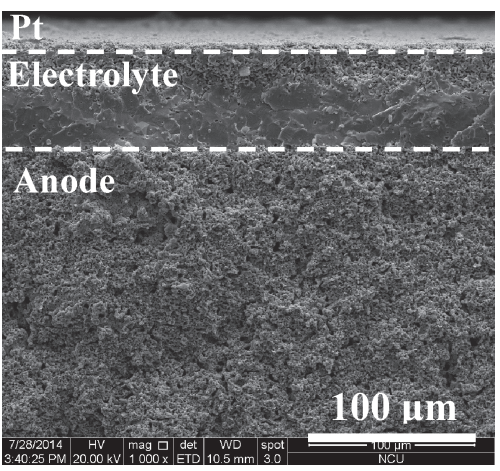

Fig. 8. The fracture morphologies of the $\mathrm{Pt} / \mathrm{Ba}_{0.8} \mathrm{Sr}_{0.2} \mathrm{Ce}_{0.75} \mathrm{In}_{0.05^{-}}$ $\mathrm{Y}_{0.2} \mathrm{O}_{3-\delta} / \mathrm{NiO}-\mathrm{Ba}_{0.8} \mathrm{Sr}_{0.2} \mathrm{Ce}_{0.6} \mathrm{Zr}_{0.2} \mathrm{Y}_{0.2} \mathrm{O}_{3-\delta}$ single cells after sintered at $1450^{\circ} \mathrm{C}$ for $4 \mathrm{~h}$.

the flatness is guaranteed and interfaces between layers are perfectly matched. Figure 8 shows the fracture surface morphologies of the $\mathrm{Pt} / \mathrm{Ba}_{0.8} \mathrm{Sr}_{0.2} \mathrm{Ce}_{0.75} \mathrm{In}_{0.05} \mathrm{Y}_{0.2} \mathrm{O}_{3-\delta} / \mathrm{NiO}-\mathrm{Ba}_{0.8} \mathrm{Sr}_{0.2^{-}}$ $\mathrm{Ce}_{0.6} \mathrm{Zr}_{0.2} \mathrm{Y}_{0.2} \mathrm{O}_{3-\delta}$ single cell sintered at $1450^{\circ} \mathrm{C}$ for $4 \mathrm{~h}$. It is notice that the electrolyte with approximate $60 \mu \mathrm{m}$ thickness is dense, only a few close pores still observed in the fracture surface. In additions, it shows a quite smooth and good adhesion between different layers. This is analogous to the results of literature report, ${ }^{19), 27)}$ a $45 \mu \mathrm{m}$ thick electrolyte performs high power density after sintering at $1450^{\circ} \mathrm{C}$. So far, it is noticed that power density of anode supported cells was reported in some literatures. Guo et al. ${ }^{28)}$ fabricated a $38 \mu \mathrm{m}$ thick BZY electrolyte by co-pressing process on Ni-BZY anode which obtained $23 \mathrm{~mW} / \mathrm{cm}^{2}$ at $600^{\circ} \mathrm{C}$. Moreover, Sun et al. ${ }^{29)}$ using the same technique obtained a 70 $\mathrm{mW} / \mathrm{cm}^{2}$ at $600^{\circ} \mathrm{C}$, fabricating a $20 \mu \mathrm{m}$ in thick and dense BZY membrane. Pergolesi et al. ${ }^{30)}$ reported remarkable results of BZY membrane of $4 \mu \mathrm{m}$ in thickness by using pulsed laser deposition (PLD) on NiO-BZY anode to achieve $110 \mathrm{~mW} / \mathrm{cm}^{2}$ at $600^{\circ} \mathrm{C}$. As a result, since the thickness of electrolyte is too thick $(60 \mu \mathrm{m})$ to obtain a higher power density. Therefore, the electrolyte thickness is required to reduce to less than $20 \mu \mathrm{m}$ for enhancing the performance of this $\mathrm{P}^{+}$-SOFC single cell in the future work.

\section{Conclusion}

In this study, single perovskite phase of $\mathrm{Ba}_{0.8} \mathrm{Sr}_{0.2} \mathrm{Ce}_{0.6} \mathrm{Zr}_{0.2} \mathrm{In}_{x^{-}}$ $\mathrm{Y}_{0.2-x} \mathrm{O}_{3-\delta}(0.0 \leqq x \leqq 0.2)$ and $\mathrm{Ba}_{0.8} \mathrm{Sr}_{0.2} \mathrm{Ce}_{0.8-x-y} \mathrm{Zr}_{y} \mathrm{In}_{x} \mathrm{Y}_{0.2} \mathrm{O}_{3-\delta}$ $(x=0.05,0.1 y=0,0.1)$ were successfully prepared using a solid state reaction process. A dense microstructure with uniform grain size of $\mathrm{Ba}_{0.8} \mathrm{Sr}_{0.2} \mathrm{Ce}_{0.75} \mathrm{In}_{0.05} \mathrm{Y}_{0.2} \mathrm{O}_{3-\delta}$ pellet is achieved when it is sintered at $1450^{\circ} \mathrm{C}$ for $4 \mathrm{~h}$. The $\mathrm{Ba}_{0.8} \mathrm{Sr}_{0.2} \mathrm{Ce}_{0.75} \mathrm{In}_{0.05^{-}}$ $\mathrm{Y}_{0.2} \mathrm{O}_{3-\delta}$ ceramic exhibits the highest conductivity of $0.011 \mathrm{~S} / \mathrm{cm}$ at $800^{\circ} \mathrm{C}$ due to its smaller lattice volume and the lower activation energy which leading to enhance the conductivity. Following the results, the performance of $\mathrm{Pt} / \mathrm{Ba}_{0.8} \mathrm{Sr}_{0.2} \mathrm{Ce}_{0.75} \mathrm{In}_{0.05} \mathrm{Y}_{0.2} \mathrm{O}_{3-\delta} /$ $\mathrm{NiO}-\mathrm{Ba}_{0.8} \mathrm{Sr}_{0.2} \mathrm{Ce}_{0.6} \mathrm{Zr}_{0.2} \mathrm{Y}_{0.2} \mathrm{O}_{3-\delta}$ anode-supported single cell can reach to $139.8 \mathrm{~mW} / \mathrm{cm}^{2}$ of powder density at $800^{\circ} \mathrm{C}$. Since the thickness of electrolyte is too thick $(60 \mu \mathrm{m})$ to obtain a higher power density, the performance of this $\mathrm{P}^{+}$-SOFC single cell is expectable to improve significantly by reducing the electrolyte to less than $20 \mu \mathrm{m}$. The $\mathrm{Ba}_{0.8} \mathrm{Sr}_{0.2} \mathrm{Ce}_{0.75} \mathrm{In}_{0.05} \mathrm{Y}_{0.2} \mathrm{O}_{3-\delta}$ ceramic is a potential electrolyte material for $\mathrm{P}^{+}-\mathrm{SOFC}$ applications.

Acknowledgement It is gratefully to acknowledge the sponsorship by Ministry of Science and Technology of Taiwan, ROC, under the Project Nos. MOST-103-3113-E008-003, NSC-102-3113-P-008008, and NSC 101-3113-P-008-006. 


\section{References}

1) E. P. Murray, T. Tsai and S. A. Barnett, Nature, 400, 649-651 (1999).

2) S. H. Chan, H. K. Ho and Y. Tian, Int. J. Hydrogen Energy, 28, 889-900 (2003).

3) S. M. Haile, Acta Mater., 51, 5981-6000 (2003).

4) Z. P. Shao and S. M. Haile, Nature, 431, 170-173 (2004).

5) W. Zhou, Z. P. Shao, R. Ran and R. Cui, Electrochem. Commun.

6) T. Ishihara, J. W. Yan, M. Shinagawa and H. Matsumoto, Electrochim. Acta, 52, 1645-1650 (2006).

7) Z. P. Shao and S. M. Haile, Nature, 431, 170-173 (2004).

8) L. Yang, C. D. Zuo, S. H. Wang, Z. Cheng and M. Liu, Adv. Mater., 20, 3280-3283 (2008).

9) W. Y. Tan, Q. Zhong, M. S. Miao and H. X. Qu, Ionics, 15, 385-388 (2009).

10) K. D. Kreuer, Annu. Rev. Mater. Res., 33, 333-339 (2003).

11) T. Takahashi and H. Iwahara, Rev Chim Miner., 17, 243-253 (1980).

12) H. Yugami, Y. Shibayama, T. Hattori and M. Ishigame, Solid State Ionics, 79, 171-176 (1995).

13) J. Guan, E. D. Stephen, B. Uthamalingam and M. L. Liu, Solid State Ionics, 110, 303-310 (1998).

14) E. Fabbri, A. D’Epifanio, E. D. Bartolomeo, S. Licoccia and E. Traversa, Solid State Ionics, 179, 558-564 (2008).

15) Magrasó, C. Frontera, A. E. Gunnæs, A. Tarancón, D. MarreroLópez, T. Norby and R. Haugsrud, J. Power Sources, 196, 9141-9417 (2011).

16) X. L. Zhou, L. M. Liu, J. M. Zhen, S. C. Zhu, B. W. Li, K. N.
Sun and P. Wang, J. Power Sources, 196, 5000-5006 (2011).

17) K. R. Lee, C. J. Tseng, J. K. Chang, I. M. Hung, J. C. Lin and S. W. Lee, Int. J. Hydrogen Energy, 38, 11097-11103 (2013).

18) E. Gorbova, V. Maragou, D. Medvedev, A. Demin and P. Tsiakaras, J. Power Sources, 181, 292-296 (2008).

19) L. Bi, S. Q. Zhang, L. Zhang, Z. T. Tao, H. Q. Wang and W. Liu, Int. J. Hydrogen Energy, 34, 2421-2425 (2009).

20) F. Giannici, A. Longo, A. Balerna, K.-D. Kreuer and A. Martorana, Chem. Mater., 19, 5714-5720 (2007).

21) M. Hung, H. W. Peng, S. L. Zheng, C. P. Lin and J. S. Wu, J. Power Sources, 193, 155-159 (2009).

22) F. Zhao, Q. Liu, S. Wang, K. Brinkman and F. Chen, J. Hydrogen Energy, 3, 4258-4263 (2010).

23) M. Amsif, D. Marrero-Lopez, J. C. Ruiz-Morales, S. N. Savvin, M. Gabás and P. Nunez, J. Power Sources, 196, 34613469 (2011).

24) S. V. Bhide and A. V. Virkar, J. Electrochem. Soc., 146, 43864392 (1999).

25) X. Chi, J. Zhang, Z. Wen, Y. Liu, M. Wu and X. Wu, J. Alloys Compd., 554, 378-384 (2013).

26) C. Zhang and H. Zhao, Solid State Ionics, 206, 17-21 (2012).

27) N. I. Matskevich, J. Therm. Anal. Calorim., 90, 955-958 (2007).

28) Y. Guo, Y. Lin, R. Ran and Z. Shao, J. Power Sources, 193, 400-407 (2009).

29) W. Sun, L. Yan, Z. Shi, Z. Zhu and W. Liu, J. Power Sources, 195, 4727-4730 (2010).

30) D. Pergolesi, E. Fabbri and E. Travers, Electrochem. Commun., 12, 977-980 (2010). 